\title{
COMMENT
}

\section{And they said it wouldn't last...}

\author{
Gregory A Petsko*
}

As years go, 2000 was an eventful one. It was, of course, the beginning of a new millennium (I know, strictly speaking that should have been 2001, but no one seriously considered doing it that way). The dreaded Y2K bug that was supposed to shut down half the world's computers proved to be nothing but a bonanza for computer consultants. George W Bush was about to be elected President of the United States, thereby proving that in my country, an ordinary bloke can grow up to be president (provided that their father had been president, they came from one of the richest and most powerful families in the land, and had been handed virtually everything they ever got on a silver plate). The most popular songs included 'It's gonna be me' by a group called 'N Sync and a rap song called 'The real Slim Shady' by Eminem. The most popular baby names for boys were Jacob, Michael, and Joshua, which might make you wonder if the whole country had been converted to Judaism, except that the most popular girls' names were Emily, Madison, and Ashley, which suggested that if it had, it had been converted to Jewish WASPs. The mostwatched television show in the US was a program called 'Survivor'. It was the first example of new concept called reality TV - a genre that was going to represent the nadir of the medium for the entire decade to come. In the movie theatres, the most popular films that year were 'Spider-Man, 'The Lord of the Rings: The Two Towers', 'Star Wars: Episode II - Attack of the Clones', and 'Harry Potter and the Chamber of Secrets' - fantasy adventures, every one. As the summer of 2000 approached, no one realized that, whereas they were immersing themselves in fake reality on television and fake unreality at the cinema, their real world was about to change forever.

On 9 June 2000, the first edition of Genome Biology appeared, both online and in print. It included a column by yours truly called 'The grail problem' [1]. The second issue, on 28 July, contained a second opinion column by the same author, this one entitled 'Dog eat dogma' [2]; it discussed how genomics was changing the Central

*Correspondence: petsko@brandeis.edu

Rosenstiel Basic Medical Sciences Research Center, Brandeis University, Waltham, MA 02454-9110, USA
Dogma of Biology from 'DNA makes RNA makes protein' to 'Sequence determines structure determines function.' You might have thought that this one-to-one mapping would have frightened most readers off, but that doesn't seem to have happened: almost 120 issues later, both the journal and this column are about to celebrate their 10th anniversary.

Genome Biology was the brainchild of many people, and I don't know who all of them were. My own dealings at that time were primarily with Miranda Robertson, Theo Bloom, and Vitek Tracz. Vitek was the founder of the open access publisher BioMed Central, and in the year 2000, open access publishing was regarded by many as a fool's dream and by many others as a threat to their way of life. Vitek, Miranda, and Theo were convinced not only that it was a viable business model, but that it was the wave of the future.

And if open access publishing was considered either heretical or ridiculous, the idea of a primarily online scientific journal was considered suicidal. Yet Genome Biology was conceived from the beginning as primarily an online publication; the print edition that went out to subscribers for the first few years was an afterthought and, frankly, looked like one.

Content was another potential problem. In January 2000, there were still a relatively small number of complete genome sequences, and nearly all of them were of prokaryotes. The founding editors and publisher of Genome Biology were betting on a revolution that really hadn't started yet in the minds of many people.

In retrospect, however, the timing couldn't have been better, because something else happened in June of 2000 besides the launch of this journal. At a gala televised press conference that featured US President Bill Clinton and UK Prime Minister Tony Blair, the publicly funded Human Genome Project and the privately funded Celera Genomics Corporation announced their simultaneous completion of the draft sequence of the human genome. And nothing in biomedical research would ever be the same again.

Yes, Genome Biology was in on the ground floor of what has been one of the greatest transformations in the history of science. What molecular biology promised, genome biology has delivered: the maturation of biology into a truly molecular discipline. Because now, at last, we 
have the parts list. In principle, we can know all the molecules that a cell can make. Of course, the magnificent irony of this knowledge is that it does us very little good without a simultaneous change in thinking that goes beyond the molecular and back to a time when whole pathways, organelles, cells and organs and organisms were studied. Thus, genome sequencing, the ultimate tool of reductionist thinking - which gave birth to metabolomics and transcriptomics and a host of other data gathering 'omics', welcome or not - has led, inevitably, to systems biology (whatever that is), and to a rebirth of the noble discipline of physiology. Like it or not, biology has become Big Science, and the Pandora's Box that genomics has opened cannot be closed again.

I have been trying to offer my personal take on this sea change in an opinion column that has appeared in every issue since the first one. The editors have allowed me free rein to do this any way I wish: satire, imaginary dialogs, even short dramas. In turn, I've tried to be provocative, imaginative, and entertaining. Whether I've succeeded or not is not for me to say. But what I can say is that I have had, thanks to this publication, a front-row seat for the kind of change in a field that comes along only once or twice in a lifetime.

Genome Biology has chronicled this metamorphosis with style and insight. The first of its kind, it remains the best of its kind in my opinion. Other journals will follow its ascent (or is it descent?) to exclusive online content with the inevitability of a sunrise. They may also imitate its unique blend of commentary, review, humor, peerreviewed science, and series. But they can't say that they saw what was coming, because few did. I think it's completely appropriate to engage in a few selfcongratulations, to which I will add mine: well done, gang.

So where do we go from here? Biology is still changing, and a journal that aims to be at the cutting edge will have to change with it. My own guess is that biological research in the age of genomics will move inexorably towards more human biology, and more direct relevance to human disease. This is partly a natural progression, but it is also driven by the increased demand that big science deliver on the promises made to convince the public to support it. Genomics was born of a promise that understanding the workings of the cell would lead to faster cures, and that promise hasn't been kept. Funding agencies and government officials and patient advocacy groups are going to hold us to that promise, and their impatience will be the prime driver for the field. To continue to be au courant, Genome Biology will need to increase its coverage not only of research related to the human genome, but also of disease-related research that makes use of both the tools and the discoveries of genomics.

The scientific changes have been amazing, and will continue to be so, but equally amazing, I think, are the changes in the culture of science that genomics has wrought. These are even harder to predict, but a good guess would be an increased rewarding of collaboration rather than an insistence that one's reputation be built entirely by one's own hands. Another might be an almost complete blurring of the lines between traditional disciplines, such that academic departments are outmoded and allegiances become fluid. Biology will also become more data-driven, quantitative, and computational than ever before, which will mean a very different sort of scientist will probably become king in this new world.

Anyway, I intend to keep writing about it all, for as long as Genome Biology exists, or until they get sick of me. Sorry about that.

Published: 5 May 2010

\section{References}

1. Petsko GA: The grail problem. Genome Biol 2000, 1:comment002.1-002.2.

2. Petsko GA: Dog eat dogma. Genome Biol 2000, 1:comment1002.1-1002.2.

doi:10.1186/gb-2010-11-5-121

Cite this article as: Petsko GA: And they said it wouldn't last... Genome Biology 2010, 11:121. 